\title{
Associations between reproductive and carcass traits in Nellore
}

\section{Associações entre características reprodutivas e de carcaça em bovinos Nelore}

\author{
Edson Junior Heitor de Paula ${ }^{1}$; Elias Nunes Martins²; \\ Carlos Antônio Lopes de Oliveira ${ }^{2}$; Cláudio de Ulhoa Magnabosco ${ }^{3}$; \\ Roberto Daniel Sainz ${ }^{4}$; Luiz Juliano Valério Geron ${ }^{1}$; Eurico Lucas de Souza Neto ${ }^{1}$; \\ Emília de Paiva Porto ${ }^{5}$ Giulianna Zilocchi Miguel ${ }^{1}$
}

\begin{abstract}
The objective of this study was to estimate the genetic parameters and (co)variance of Nellore animals and to characterize the associations between these characteristics for the following carcass traits: weight (W), longissimus muscle area (LMA), rump fat thickness (RF) and fat thickness between the 12th and 13th ribs obtained by ultrasound (BF); also, the following reproductive traits: age at first calving (AFC), first calving interval (FCI), scrotal circumference at 450 and 550 days of age (SC450 and SC550). The genetic parameters were estimated by a single-trait and two traits animal model using Bayesian inference. The model used for all of the features included the genetic random effect and age as covariate assuming a quadratic effect. Additionally, sex, month and year of birth and management of creation and environmental effects identified were included for the carcass traits. For AFC, FCI and SC450 and SC550, we considered only the month and year of birth. The heritability estimates for all of the traits were higher in the two traits analysis, except for AFC and FCI, which showed 0.75 and 0.29 , respectively, similar values in the single trait analysis. The two traits analyses resulted in heritability estimates for a posteriori for the features W, LMA, BF, RF, SC450 and SC550 of 0.49, 0.66, 0.74, 0.68 0.66 and 0.74 , respectively, suggesting the possibility of genetic gains during a short period of time. The genetic correlations between AFC and carcass traits measured by ultrasound were close to zero. A similar trend was found for AFC, SC450 and SC550 days, indicating that the selection for these traits does not promote changes in AFC. High genetic correlations (0.92, 0.93 and 0.94) were observed between the characteristics LMA and W, BF and RF, and SC450 and SC550, respectively.

Key words: Bayesian inference, Bos indicus, genetic parameters, sexual precocity, ultrasound
\end{abstract}

\section{Resumo}

Objetivou-se com este trabalho estimar os parâmetros genéticos e os componentes de (co)variância para as características de carcaça: peso (PESO), área de olho de lombo (AOL), espessura de gordura subcutânea na garupa (EGP8) e entre a 12 $2^{\mathrm{a}}$ e $13^{\mathrm{a}}$ costelas obtidas por ultrassom (EG); para as características ligadas

\footnotetext{
${ }^{1}$ Profs. Drs., Pesquisadores, Universidade do Estado de Mato Grosso, UNEMAT, Pontes e Lacerda, MT, Brasil. E-mail: edsonjr@, unemat.br; ljgeron@unemat.br; euriconeto@unemat.br; giulianna@unemat.br

2 Profs. Drs., Pesquisadores, Universidade Estadual de Maringá, UEM, Maringá, PR, Brasil. E-mail: enmartins@uem.br; caloliveira@uem.br.

3 Prof. Dr., Pesquisador, Embrapa Cerrados/Arroz e Feijão, CPAC/CNPAF, Santo Antônio, GO, Brasil. E-mail: claudio. magnabosco@embrapa.br

4 Prof. Dr., Pesquisador, Universidade da Califórnia, UCDAVIS, Davis, CA, Estados Unidos. E-mail: rdsainz@ucdavis.edu

${ }^{5}$ Prof $^{a}$ Dr $^{\text {a }}$, Pesquisadora, Universidade Estadual do Norte do Paraná, UENP, Bandeirantes, PR, Brasil. E-mail: emilia@uenp.edu.br

* Author for correpondence
} 
à reprodução: idade ao primeiro parto (IPP), primeiro intervalo entre partos (PIEP), perímetro escrotal aos 450 e 550 dias de idade (PE450 e PE550) de animais da raça Nelore e verificar as associações entre estas características. Os parâmetros genéticos foram estimados em análises uni e bicaracter, em um modelo animal, por meio da inferência Bayesiana. O modelo utilizado, para todas as características, incluiu o efeito aleatório genético e a idade como covariável assumindo efeito quadrático. Incluiu também sexo, mês, ano de nascimento e manejo de criação como efeitos ambientais identificáveis para as características de carcaça. Para IPP, PIEP, PE450 e PE550, foram considerados apenas mês e ano de nascimento. As estimativas de herdabilidade de todas as características estudadas foram maiores nas análises bicaracter exceto para IPP e PIEP, que apresentaram 0,75 e 0,29, respectivamente, valores semelhantes nas análises unicaracter. As análises bicaracter resultaram em estimativas de herdabilidade a posteriori para as características PESO, AOL, EG, EGP8, PE450 e PE550 de 0,49, 0,66, 0,74, 0,68, 0,66 e 0,74 respectivamente, sugerindo a possibilidade de ganhos genéticos em curto prazo de tempo. As correlações genéticas entre IPP e as características de carcaça medidas por ultrassom foram próximas de zero. Comportamento semelhante foi encontrado para IPP, PE450 e PE550 dias indicando que a seleção para essas características não promoverá mudanças na IPP. Correlações genéticas altas $(0,92,0,93$ e 0,94$)$ foram encontradas entre as características AOL e PESO, EG e EGP8 e PE450 e PE550, respectivamente. Palavras-chave: Bos indicus, inferência Bayesiana, parâmetros genéticos, precocidade sexual, ultrassom

\section{Introduction}

The programs of genetic improvement of beef cattle in Brazil have primarily investigated the characteristics of ponderal development; however, other relevant characteristics must be included in the selection programs. Among these characteristics, carcass characteristics and characteristics related to reproduction should be assessed.

Many characteristics, including puberty age, age at first calving (AFC), first carving interval (FCI), scrotal circumference (SC), among other ones, have been studied to improve female reproductive development, but there is no consensus regarding the most appropriate characteristics.

In addition to exhibiting no direct economic benefits, the selection to increase the scrotal circumference has been used under the argument that this characteristic is genetically correlated to many reproductive characteristics of the male and female (BERGMANN, 1993) and to characteristics of ponderal development. Because of its positive genetic association with characteristics of development, the increase of the scrotal circumference might also result in weight gain maturity. This effect is a reason of concern when the goal is to improve the herd reproductive efficiency because animals of a higher asymptotic weight tend to be later in cases of no changes in the system of feeding these animals.

The carcass characteristics according to Alencar et al. (1999) must be included in the selection programs because the consumer market demands higher quality and competitively priced meat, including other protein sources. According to Boleman et al. (1998), among other factors that affect the quality of the carcass, the percentage of subcutaneous and intramuscular fat in addition to meat tenderness must be highlighted.

According to OWENS et al. (1993), the body tissues grow and develop under waves of specific growth, beginning in the nervous system followed by the bones and muscular tissues and, finally, by the adipose tissue; however, by identifying animals with a higher percentage of subcutaneous fat, these animals would be hypothesized to be sexually precocious because they would be of mature weight.

The association of the carcass characteristics and reproductive characteristics has not been thoroughly examined for Nellore cattle, and according to Magnabosco et al. (2009) there are conflicting data mentioned in literature. Thus, more studies are needed to obtain a greater reliability regarding the carcass characteristics and sexual precocity. 
The goal of this study was to estimate the genetic parameters and the components of (co) variance of Nellore cattle animals and to investigate the associations between these characteristics for the following carcass characteristics: weight, longissimus muscle area, rump fat thickness and between the $12^{\text {th }}$ and $13^{\text {th }}$ ribs cut obtained through ultrasound; additionally, the following characteristics related to reproduction: AFC, FCI, scrotal circumference on 450 and 550 days of age.

\section{Materials and Methods}

Nellore beef cattle collected at Fazenda Guaporé, owned by the company Guaporé Pecuária - OB trademark, located $450 \mathrm{~km}$ distant from Cuiabá, in Pontes e Lacerda city, southeast of Mato Grosso state were used in this study. The herd is a part of the Nellore Brazil Genetic Improvement Program of the National Association of Breeders and Researchers, which provided the genealogy of 66.057 animals of the numerator relationship matrix. Two databases were employed in this study. The first one provided the carcass information of 8.984 animals measured by ultrasound and collected by a trained technician that used Aloka $500 \mathrm{~V}$ equipment with a linear probe of $17.2 \mathrm{~cm}, 3.5 \mathrm{MHz}$ and an acoustic couple (standoff). To obtain an image of the longissimus muscle area (LMA) and the thickness of the back fat, the transducer was placed perpendicular to the back bone, transversally over the Longissimus dorsi muscle between the $12^{\text {th }}$ and $13^{\text {th }}$ ribs cut using standoff. To obtain an image of the rump fat thickness (RF), the transducer was placed on the intersection of the Gluteus medius and Biceps femoris muscles, placed between the ileum and ischeum. During the collection of the ultrasound data, the weight of Nellore male and females that were aged 20 months on average and were born between 2000 and 2010 was collected. The second data bank stored the information regarding the reproductive characteristics of 9.863 animals of both sexes born between 1992 and 2008. This bank contained information regarding the age at first calving (AFC), obtained through the difference between the first calving and the birth of the animal, the first calving interval (FCI), the time between the first and the second calvings and the scrotal circumference standardized on 450 and 550 days of age.

Estimates of (co)variance components and the genetic parameters of all of the analyzed characteristics were obtained using a Bayesian approach, through the Gibbs sampling method of MTGSAM (Multiple Trait Gibbs Sampling in Animal Models) program, developed by Van Tassel and Van Vleck (1996).

At first unicharacter analyses were carried out for each characteristic, and later, bicharacter analyses were performed using the model:

$y=X \beta+Z a+e$

in which:

$\mathrm{y}=$ observation vector;

$\beta=$ identifiable environmental effects vector;

$\mathrm{a}=$ direct genetic values vector;

$\mathrm{X}$ e $\mathrm{Z}=$ incidence matrices of identifiable environmental effects and direct genetics, respectively;

$e=$ residual effects vector, associated to vectors $\mathrm{Y}$.

$y$, a and $e$ vectors were assumed to have multivariate joint normal distribution:

$$
\left[\begin{array}{l}
y \\
a \\
e
\end{array}\right] \sim N M V\left\{\left[\begin{array}{l}
\mathrm{X} \beta \\
0 \\
0
\end{array}\right] ;\left[\begin{array}{ccc}
\mathrm{Z} G \mathrm{Z}^{\prime}+R & \mathrm{ZG} & R \\
G \mathrm{Z}^{\prime} & G & 0 \\
R & 0 & R
\end{array}\right]\right\}
$$

in which, the unicharacter analyses, $\mathrm{G}$ is the matrix of genetic (co) variances, presented as $A \sigma_{a}^{2}, A$ is the matrix of kinship between the animals and $\sigma_{a}^{2}$, the genetic variance of the characteristic; $R$ is a matrix of residual variance presented by $I \sigma_{e}^{2}, I$ is the identity matrix of the same order of the number of animals and $\sigma_{e}^{2}$ the residual variance of the characteristic. 
For the bicharacter analyses, $\mathrm{G}$ is the matrix of genetic (co)variance presented as $G_{o} \otimes A, A i$ is the kinship matrix between the animals and $G_{o}$ the matrix of genetic (co)variance between the characteristics, $R$ is the matrix of residual (co) variances presented as $R_{o} \otimes I, I$ is the identity matrix of the same order of the number of animals and $R_{o}$ the matrix of residual (co)variances between the characteristics, as follows:

$$
G_{o}=\left[\begin{array}{cc}
\sigma_{a_{1}}^{2} & \sigma_{a_{1} a_{2}} \\
\sigma_{a_{2} a_{1}} & \sigma_{a_{2}}^{2}
\end{array}\right] \quad R_{o}=\left[\begin{array}{cc}
\sigma_{e_{1}}^{2} & \sigma_{e_{1} e_{2}} \\
\sigma_{e_{2} e_{1}} & \sigma_{e_{2}}^{2}
\end{array}\right]
$$

The model used for all of the characteristics includes the genetic random effect and the age as a covariate assuming the quadratic effect. The model also included gender, month, year of birth and breeding management as identifiable environmental effects for weight and for the characteristics obtained by ultrasound (LMA, FT, RF). For AFC, FCI, SC450 and SC550 characteristics, only month and year of birth were considered to be identifiable environmental effects.

Contemporary groups were not formed because the animals belonged to an only farm.

For the a priori values of additive and residual (co)variances. a non-informative distribution (not reflecting on the previous knowledge of the parameter) was used. A priori uniform distribution was assumed for the identifiable environmental effects and for the components of variance reverse gamma distribution for the unicharacter analyses and Wishart inverse for the bicharacter analyses.

For the unicharacter and bicharacter analyses, Gibbs chains of 200.000 and 1.000 .000 interactions were created, with $20 \%$ of the initial disposal and sampling interval of 50 interactions, resulting in 3.600 and 16.000 samples of (co)variance components for each analyses, respectively.

The monitoring of convergence of chains generated by the Gibbs sampler was performed through graphic analyses and through the use of Geweke e de Heidelberger \& Welch diagnostic tests, available on CODA (Convergence Diagnosis and Output Analysis), implemented on R program (R DEVELOPMENT CORE TEAM, 2012).

The reliability intervals were built, and the regions of high density for all of the (co)variance components and estimated genetic parameters were established at $95 \%$.

\section{Results and Discussion}

The statistics presenting the number of observations, average, standard deviation, minimum and maximum values of the carcass characteristics and characteristics related to reproduction in addition to the number of bulls and matrices of the animals used in this study are listed in Table 1.

Table 1. Descriptive summary of reproductive characteristics and carcass traits of the Nellore animals used in this study.

\begin{tabular}{clccccccc}
\hline \multicolumn{2}{c}{ Characteristic } & $\mathrm{N}$ & Average & SD & Min & Max & Bulls & Matrices \\
\hline \multirow{6}{*}{ Carcass } & WEIGHT $(\mathrm{kg})$ & 8.984 & 322.09 & 50.26 & 156.00 & 852.00 & 347 & 5.284 \\
& LMA $\left(\mathrm{cm}^{2}\right)$ & 8.911 & 48.16 & 8.32 & 21.53 & 114.10 & 347 & 5.226 \\
& FT $(\mathrm{mm})$ & 8.918 & 2.14 & 0.79 & 0.15 & 11.70 & 347 & 5.228 \\
& RF $(\mathrm{mm})$ & 8.890 & 2.48 & 0.93 & 0.13 & 12.10 & 347 & 5.208 \\
\hline \multirow{5}{*}{ Reproduction } & AFC (days) & 7.630 & 1338 & 377 & 708 & 4916 & 386 & 4.752 \\
& FCI (days) & 7.506 & 498 & 145 & 276 & 1797 & 386 & 4.696 \\
& SC450 (cm) & 9.285 & 21.16 & 2.52 & 15.00 & 37.00 & 397 & 5.951 \\
& SC550 $(\mathrm{cm})$ & 9.863 & 24.37 & 2.89 & 16.00 & 38.00 & 399 & 6.245 \\
\hline
\end{tabular}

N: number of animals; SD: standard deviation; Min: minimum value; e Max: maximum value, of the following characteristics: WEIGHT; LMA: longissimus muscle area; FT: fat thickness between $12^{\text {th }}$ and $13^{\text {th }}$ ribs; RF: rump fat thickness, between ileum and ischio; AFC: age at first calving; FCI: first calving interval; SC450 and SC550: scrotal circumference at 450 and 550 days of age, respectively. 
The measures obtained for the longissimus muscle area, fat thickness and rump fat thickness were $48.16 \mathrm{~cm}^{2}, 2.14 \mathrm{~mm}$ and $2.48 \mathrm{~mm}$, respectively. Similar values, $48.38 \mathrm{~cm}^{2}$ for LMA, $1.93 \mathrm{~mm}$ for FT e 3.05 for BFT, were described by Yokoo et al. (2009) that also worked with Nellore animals. Slightly lower estimates were reported by Magnabosco et al. (2009) that presented an average of $42.71 \mathrm{~cm}^{2}$ for LMA; FT of $1.40 \mathrm{~mm}$ and 1.84 $\mathrm{mm}$ for BFT, justified because the animals were slightly younger, with ages ranging between 15 and 19 months. The values of BFT were superior to FT, suggesting that the back fat deposition starts earlier than the ribs, corroborating the results of the studies mentioned previously.

The average number of days between the age at first calving and the first calving interval was 1.338 and 498 days, which was superior to several studies in the literature for AFC on Nellore animals, where $1.050,1.104,1.130$ and 1.149 days were reported by Grossi et al. (2009), Boligon et al. (2007), Pereira et al. (2001) and Mercadante et al. (2000), respectively. Similar results of AFC (1.279 days) were reported by Silveira et al. (2004) and for FCI were reported by Mercadante et al. (2000) and Yokoo et al. (2012). The average results for AFC and
FCI in this study indicate the need of the inclusion of these characteristics as a selection criteria in this herd.

The standardized average for scrotal circumference at 450 and 550 days of age were 21.16 and $24.37 \mathrm{~cm}$, respectively. Grossi et al. (2009) reported higher measurements for SC450 and SC550 (23.2 and $26.5 \mathrm{~cm})$. The scrotal circumference measurement at yearling (550 days) was below the scale of described values in the literature as 26 to $28.3 \mathrm{~cm}$ (PEREIRA et al., 2000; FORNI; ALBUQUERQUE, 2005; BOLIGON et al., 2007).

For all of the analyses, both unicharacter and bicharacter, there was a convergence indication of chains through graphical analysis and through Geweke and Heidelberger and Welch diagnostic tests, as performed in the $\mathrm{R}$ program ( $\mathrm{R}$ DEVELOPMENT CORE TEAM, 2012).

In Tables 2 and 3, the posteriori estimates of variance and heritability components for the carcass characteristics (Table 2) and the characteristics related to reproduction (Table 3 ) and the respective intervals of reliability and high density regions at $95 \%$, as obtained through unicharacter analysis, are presented.

Table 2. Estimates of (co)variance and heritability $\left(h^{2}\right)$ components for the carcass characteristics, weight, longissimus muscle area (LMA), fat thickness between $12^{\text {th }}$ and $13^{\text {th }}$ ribs (FT), rump fat thickness (RF) and its respective reliability intervals and high density region at $95 \%$, obtained through unicharacter analyses.

Continue ...

\begin{tabular}{cccccc}
\hline Characteristics & Parameters & Averages & $\begin{array}{c}\text { Standard } \\
\text { Deviation }\end{array}$ & Reliability interval & $\begin{array}{c}\text { High density } \\
\text { region }\end{array}$ \\
\hline & $\sigma_{a}^{2}$ & 768.63 & 57.77 & $660.82-887.75$ & $658.40-884.55$ \\
WEIGHT & $\sigma_{e}^{2}$ & 1.442 .16 & 45.34 & $1353-1531$ & $1353-1530$ \\
& $\sigma_{f}^{2}$ & 2.210 .80 & 37.27 & $2.139-2.284$ & $2.141-2.285$ \\
& $h^{2}$ & 0.34 & 0.02 & $0.30-0.39$ & $0.30-0.39$ \\
\hline
\end{tabular}


Continuation

\begin{tabular}{cccccc}
\hline & $\sigma_{a}^{2}$ & 22.70 & 1.78 & $19.40-26.38$ & $19.34-26.31$ \\
& $\sigma_{e}^{2}$ & 32.51 & 1.32 & $29.87-35.09$ & $29.98-35.17$ \\
& $\sigma_{f}^{2}$ & 55.22 & 0.98 & $53.36-57.22$ & $53.42-57.26$ \\
& $h^{2}$ & 0.41 & 0.02 & $0.35-0.46$ & $0.35-0.46$ \\
\hline FT & $\sigma_{a}^{2}$ & 0.06 & 0.01 & $0.05-0.07$ & $0.05-0.07$ \\
& $\sigma_{e}^{2}$ & 0.25 & 0.01 & $0.24-0.26$ & $0.24-0.26$ \\
& $\sigma_{f}^{2}$ & 0.31 & 0.01 & $0.30-0.32$ & $0.30-0.32$ \\
& $h^{2}$ & 0.20 & 0.02 & $0.15-0.24$ & $0.15-0.23$ \\
\hline$\sigma_{a}^{2}$ & 0.17 & 0.02 & $0.14-0.20$ & $0.14-0.20$ \\
\hline$\sigma_{a}^{2}=$ additive genetic variance, $\sigma_{e}^{2}=$ residual variance, $\sigma_{f}^{2}=$ phenotypic variance and $h^{2}=$ heritability. &
\end{tabular}

The values of reliability intervals and high density region to each estimated parameter are notably close to each other, being coincident to some, indicating that there is a symmetry on the posteriori distribution of all of the estimated parameters.

The posteriori estimates for the genetic parameters including AFC, FCI, SC450, SC550, WEIGHT, LMA, FT and BFT and the respective reliability intervals at $95 \%$ in the bicharacter analyses are presented in Table 4.

When comparing heritability obtained through the unicharacter (Tables 2 and 3) and bicharacter analyses (Table 4), to the same characteristics, there was an increase in the estimation of this parameter when the bicharacter model is used. This result was expected because according to Eler et al. (1996), these models consider the correlation between the characteristics to increase the accuracy of the prediction of genetic value. In this study, this statement was valid to the analyses of all of the characteristics, except for age at first calving and first calving interval. Magnabosco et al. (2009) reported that the analyses involving more than one characteristic simultaneously presented more accuracy on the predictions of genetic values due to the additional information incorporated, especially by the components of (co) variance between the characteristics. 
Table 3. Estimates for (co)variance and heritability $\left(h^{2}\right)$ components for the reproductive characteristics, age at first calving (AFC), first calving interval (FCI), scrotal circumference at 450 and 550 days of age (SC450 and SC550) and the respective reliability intervals and high density region at $95 \%$, obtained through unicharacter analyses.

\begin{tabular}{|c|c|c|c|c|c|}
\hline Characteristics & Parameters & Average & $\begin{array}{c}\text { Standard } \\
\text { Deviation }\end{array}$ & Reliability interval & $\begin{array}{l}\text { High density } \\
\text { region }\end{array}$ \\
\hline \multirow{4}{*}{$\mathrm{AFC}$} & $\sigma_{a}^{2}$ & 56.390 & 2.516 & $51.550-61.350$ & $51.477-61.264$ \\
\hline & $\sigma_{e}^{2}$ & 18.040 & 1.543 & $15.060-21.080$ & $15.090-21.106$ \\
\hline & $\sigma_{f}^{2}$ & 74.430 & 1.470 & $71.680-77.410$ & $71.652-77.360$ \\
\hline & $h^{2}$ & 0.75 & 0.02 & $0.71-0.80$ & $0.71-0.80$ \\
\hline \multirow{4}{*}{ FCI } & $\sigma_{a}^{2}$ & 6.520 & 632.58 & $5.337-7.824$ & $5.294-7.761$ \\
\hline & $\sigma_{e}^{2}$ & 15.170 & 525.41 & $14.127-16.200$ & $14.137-16.206$ \\
\hline & $\sigma_{f}^{2}$ & 21.690 & 394.27 & $20.942-22480$ & $20.929-22.469$ \\
\hline & $h^{2}$ & 0.30 & 0.02 & $0.25-0.35$ & $0.24-0.35$ \\
\hline \multirow{4}{*}{ SC450 } & $\sigma_{a}^{2}$ & 2.55 & 0.18 & $2.19-2.93$ & $2.19-2.92$ \\
\hline & $\sigma_{e}^{2}$ & 3.91 & 0.13 & $3.63-4.18$ & $3.63-4.18$ \\
\hline & $\sigma_{f}^{2}$ & 6.46 & 0.10 & $6.26-6.69$ & $6.25-6.68$ \\
\hline & $h^{2}$ & 0.39 & 0.02 & $0.34-0.44$ & $0.34-0.44$ \\
\hline \multirow{4}{*}{ SC550 } & $\sigma_{a}^{2}$ & 4.16 & 0.26 & $3.65-4.67$ & $3.66-4.69$ \\
\hline & $\sigma_{e}^{2}$ & 4.30 & 0.18 & $3.94-4.68$ & $3.93-4.67$ \\
\hline & $\sigma_{f}^{2}$ & 8.47 & 0.14 & $8.19-8.75$ & $8.18-8.74$ \\
\hline & $h^{2}$ & 0.49 & 0.02 & $0.43-0.54$ & $0.44-0.54$ \\
\hline
\end{tabular}

The values obtained in this study for weight heritability estimates, longissimus muscle area, fat thickness on the $12^{\text {th }}$ and $13^{\text {th }}$ ribs and rump fat thickness were consistent with the literature for Nellore animals. (FIGUEIREDO et al., 2000; ALBUQUERQUE; OLIVEIRA, 2002; BARBOSA, 2005; MAGNABOSCO et al., 2006, 2009; YOKOO et al., 2008, 2009) reported high heritability rates $(0.49,0.66,0.74$ and 0.68 , respectively), indicating the variations of these characteristics due to an additive effect of shared genes, presenting selection as an effective instrument to obtain genetic changes in populations for the mentioned characteristics.

Assuming the Bourdon criteria (1997), the heritability estimates are in the moderate range from 0.20 to 0.39 and high above 0.40 , the FCI characteristic presented high heritability, $0.75 \pm$ 0.02 and the region of high density ranging from 0.71 to 0.80 , indicating there is genetic variability in this characteristic in this herd (Table 3). 


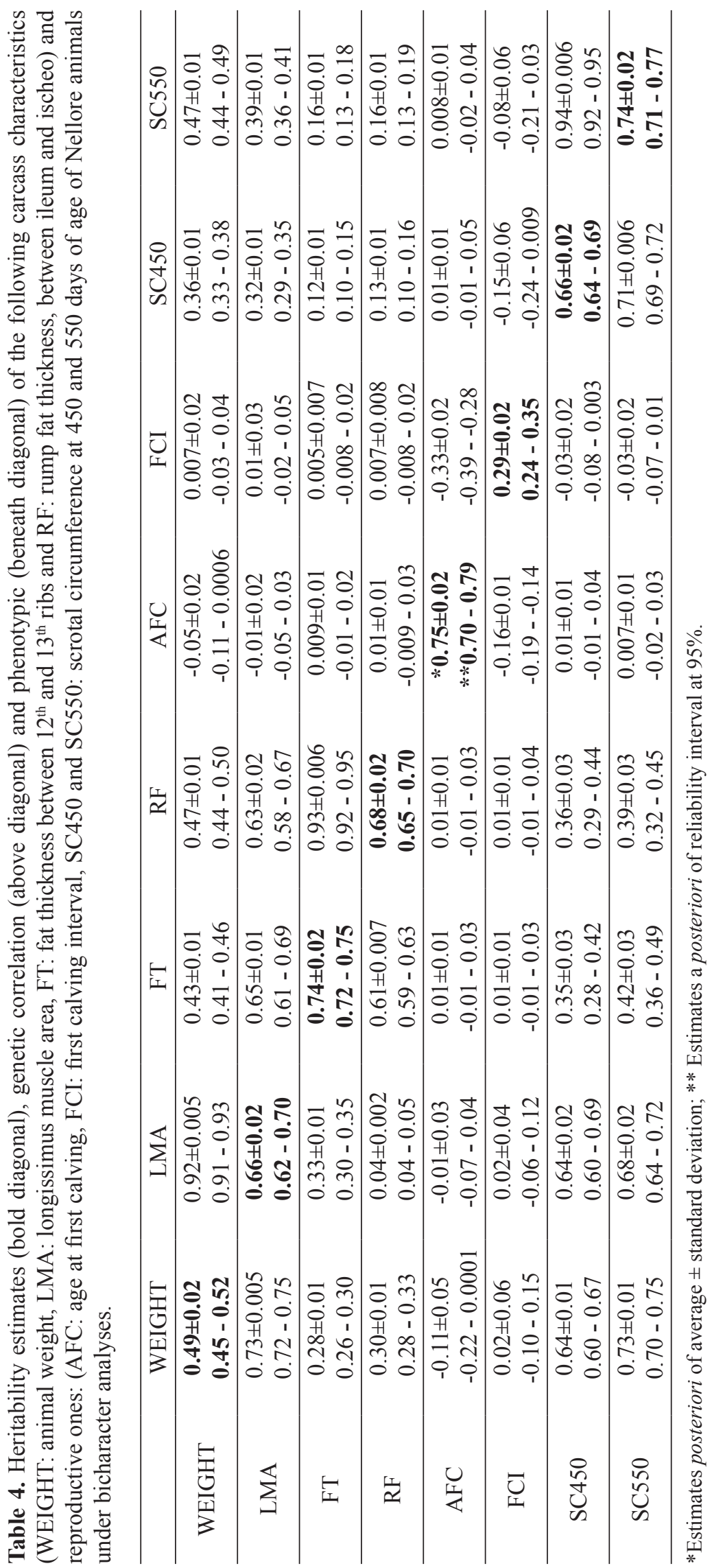


The heritability estimates for AFC found on literature are usually low (PEREIRA et al., 2000, 2001; TALHARI et al., 2003; GRESSLER et al., 2000; BOLIGON et al., 2007, 2010); however, moderate estimates were also reported (MERCADANTE et al., 2000; YOKOO, 2009; DIAS et al., 2003). The high heritability for AFC obtained in this study can be attributed to the manner in which this characteristic was studied, including the meticulous data collection that occurred at the property, the inclusion of all herd females and the non-formation of contemporary groups. Therefore, all of the animals had similar breeding conditions (feeding, management and climate), which might have reduced the influence of these factors on heritability. According to Mercadante et al. (2000) and Dias et al. (2004), the inclusion of all females born in the herd and not only the females put into reproduction provides an increase in the genetic variability for AFC. Additionally, the inclusion of year and season at calving on the formation of contemporary groups likely decreased a part of the existing genetic variation for $\mathrm{AFC}$, thus affecting the heritability estimate.

The heritability estimate for FCI presented a moderate magnitude under the average value of 0.29 and reliability interval and region of high density from 0.24 to 0.35 (Table 4). Similar results were reported by Campello et al. (1999) and Silveira et al. (2004).

The characteristics SC450 and SC550 presented high heritability rates, 0.66 and 0.74 , respectively, consistent with the results reported by Boligon et al. (2007), Magnabosco et al. (2009) and Pereira et al. (2010).

The estimates of phenotypic correlations between all of the studied characteristics were always lower than the estimates of the corresponding genetic correlations, consistent with the report by Ferraz Filho et al. (2002).

The genetic correlations between AFC and the carcass characteristics measured by ultrasound were close to zero, negating the hypothesis that animals with a higher carcass fat thickness would be sexually premature. A similar behavior was found for AFC and SC450 and SC550 days of age, indicating that the selection of these characteristics does not promote changes on AFC. These results are consistent with the report by Yokoo et al. (2009) and contradict the results reported by Pereira et al. (2002) and Boligon et al. (2007), which found a genetic correlation of AFC with SC550 medium magnitude negative, indicating that the selection of breeders with a higher scrotal circumference correlated with a reduction of the age at first calving.

There was a low negative genetic association $(-0.33 \pm 0.02)$ between AFC and FCI, indicating that the older animals at first calving presented lower intervals between the first and second calving. This result was expected because premature animals at first calving are still under considerable body development when facing a sudden increase of nutritional demand of milk production immediately after the calving, which reduces the return to reproductive time.

The genetic correlations between FCI and all of the other characteristics studied were close to zero and corroborated the results described by Yokoo et al. (2012).

High genetic correlations $(0.92 \pm 0.005$, $0.93 \pm 0.006$ and $0.94 \pm 0.006)$ were found between LMA and WEIGHT, FT and RF and between the SC450 and SC550 characteristics, respectively. These results indicated that these characteristics are determined, in great portion, by the same group of genes of additive action and that the selection will bring, simultaneously, genetic progress for the other one.

For a high correlation for RF and FT, in selection programs that aim to improve carcass conformation, RF must be included as a selection criteria. According to Faria et al. (2009), rump fat thickness is an interesting characteristic only for animals raised on pasture because of the earlier deposition 
than the rib fat and for presenting a greater accuracy and measurement repeatability compared to FT.

The fat thickness measured between the $12^{\text {th }}$ and $13^{\text {th }}$ ribs and RF presented a genetic correlation of low magnitude (0.35 to 0.39 ) under the scrotal circumference on 450 and 550 days of age. Even lower values (0.06 and 0.09 ) were reported by Magnabosco et al. (2009), which correspond to the values obtained by Yokoo (2009). For the PE450 and PE550 characteristics and longissimus muscle area, PESO moderate to high correlations were obtained ( 0.64 and $0.73,0.64$ to 0.68 , respectively). These results indicate that the selection of any of these characteristics will produce a result correlated in the same direction as the other one; however, Robertson (1959) suggested that when a genetic correlation between two characteristics is lower than 0.80 , both must be considered regarding selection programs.

The inclusion of SC450 and SC550 as a selection criteria does not lead to a genetic gain on sexual precocity, and the genetic association of these characteristics under asymptotic weight must be investigated because the inclusion of these characteristics as a selection criteria may lead to an inconvenient increase on mature weight that is directly associated to late finishing.

\section{Conclusions}

All of the studied characteristics presented high heritability levels, except for the first calving interval. which presented a moderate magnitude to this genetic parameter and must therefore respond to selection.

The direct selection for the rib eye area results in a genetic gain of weight and, in the long term, a scrotal circumference on 450 and 550 days of age and the rib and rump fat thickness.

Earlier animals at first calving tend to present higher intervals between the first and second calvings.

\section{Acknowledgments}

To Guaporé pecuária OB trademark, to National Association of Breeders and Researchers and Aval Technological Services, for providing the database. To Mato Grosso State University, for the opportunity for qualification; to Foundation of Research Support of Mato Grosso State, for the scholarship and to postgraduate program in Husbandry at Maringá State University.

\section{References}

ALBUQUERQUE, L. G.; OLIVEIRA, H. N. Genetic parameter estimates for ultrasound measurements and visual scores in Nelore cattle. In: ANNUAL MEETING OF THE EAAP, 53., 2002, Cairo. Proceedings... Cairo: EAAP, 2002. CD-ROM.

ALENCAR, M. M.; BARBOSA, R. T.; NOVAES, A. P. Características produtivas e reprodutivas de fêmeas da raça Nelore e cruzadas $1 / 2$ Canchim $+1 / 2$ Nelore. Revista Brasileira de Zootecnia, Viçosa, MG, v. 28, n. 5, p. 960967, 1999.

BARBOSA, V. Inferência bayesiana no estudo genético quantitativo de características de carcaça, utilizando a técnica de ultra-sonografia, e suas relações com o peso e perímetro escrotal, em novilhos da raça Nelore. 2005. Dissertação (Mestrado em Ciência Animal) Universidade Federal de Goiás, Goiânia.

BERGMANN, J. A. G. Melhoramento genético da eficiência reprodutiva em bovinos de corte. Revista Brasileira de Reprodução Animal, Belo Horizonte, v. 1, n. 4, p. 70-86, 1993.

BOLEMAN, S. L.; BOLEMAN, S. J.; MORGAN, W. W.; HALE, D. S.; GRIFFIN, D. B.; SAVELL, J. W.; AMES, R. P.; SMITH, M. T.; TATUM, J. D.; FIELD, T. G.; SMITH, G. C.; GARDNER, B. A.; MORGAN, J. B.; NORTHCUTT, S. L.; DOLEZAL, H. G.; GILL, D. R.; RAY, F. K. National beef quality audit-1995: survey of producer-related defects and carcass quality and quantity attributes. Journal of Animal Science, Champaign, v. 76, n. 1, p. 96-103, 1998.

BOLIGON, A. A.; ALBUQUERQUE, L. G.; MERCADANTE, M. E. Z.; LOBO, R. B. Study of relations among age at first calving, average weight gains and weights from weaning to maturity in Nellore cattle. Revista Brasileira de Zootecnia, Viçosa, MG, v. 39, n. 4, p. 746-751, 2010. 
BOLIGON, A. A.; RORATO, P. R. N.; ALBUQUERQUE, L. G. Correlações genéticas entre medidas de perímetro escrotal e características produtivas e reprodutivas de fêmeas da raça Nelore. Revista Brasileira de Zootecnia, Viçosa, MG, v. 36, n. 3, p. 566-571, 2007.

BOURDON, R. M. Understanding animal breeding. New Jersey: Colorado State University, 1997. 523 p.

CAMPELLO, C. C.; MARTINS FILHO, R.; LOBO, R. N. B. Intervalos de parto e fertilidade real em vacas Nelore no estado do Maranhão. Revista Brasileira de Zootecnia, Viçosa, MG, v. 28, n. 3, p. 474-479, 1999.

DIAS, L. T.; EL FARO, L.; ALBUQUERQUE, L. G. Efeito da idade de exposição de novilhas à reprodução sobre estimativas de herdabilidade da idade ao primeiro parto em bovinos Nelore. Arquivo Brasileiro de Medicina Veterinária e Zootecnia, Belo Horizonte, v. 56, n. 3, p. 370-373, 2004.

Estimativas de herdabilidade para perímetro

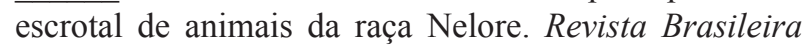
Zootecnia, Viçosa, MG, v. 32, n. 6, p. 1878-1882, 2003.

ELER, J. P.; FERRAZ, J. B. S.; SILVA, P. R. Parâmetros genéticos para peso, avaliação visual e circunferência escrotal na raça Nelore, estimados por modelo animal. Arquivo Brasileiro de Medicina Veterinária e Zootecnia, Belo Horizonte, v. 48, n. 3, p. 203-213, 1996.

FARIA, C. U.; MAGNABOSCO, C. U.; ALBUQUERQUE, L. G.; BEZERRA, L. A. F.; LOBO, R. B. Estimativas de correlações genéticas entre escores visuais e características de carcaça medidas por ultrassonografia em bovinos Nelore utilizando modelos bayesianos linear-limiar. Revista Brasileira de Zootecnia, Viçosa, MG, v. 38, n. 11, p. 2144-2151, 2009.

FERRAZ FILHO, P. B.; RAMOS, A. A.; SILVA, L. O. C.; SOUZA, J. C.; ALENCAR, M. M. Herdabilidade e correlações genéticas, fenotípicas e ambientais para pesos em diferentes idades de bovinos da raça Tabapuã. Archives of Veterinary Science, Curitiba, v. 7, n. 1, p. 6569, 2002.

FIGUEIREDO, L. G. G.; ELER, J. P.; FERRAZ, J. B. S. OLIVEIRA, F. F.; SHIMBO, M. V.; JUBILEU, J. S. Componentes de variância para área de olho de lombo e espessura de gordura subcutânea. In: SIMPÓSIO DA SOCIEDADE BRASILEIRA DE MELHORAMENTO ANIMAL, 3., 2000, Belo Horizonte. Anais... Belo Horizonte: SBMA, 2000. p. 385-387.

FORNI, S.; ALBUQUERQUE, L. G. Estimates of genetic correlations between days to calving and reproductive and weight traits in Nelore cattle. Journal of Animal Science, Champaign, v. 83, p. 1511-1515, 2005.
GRESSLER, L. S.; BERGMANN, J. A. G.; PEREIRA, C. S.; PENNA, V. M.; PEREIRA, J. C. C. GRESSLER, M. G. M. Estudo das associações genéticas entre perímetro escrotal e características reprodutivas de fêmeas Nelore. Revista Brasileira de Zootecnia, Viçosa, MG, v. 29, n. 2, p. 427-437, 2000.

GROSSI, D. A.; VENTURINI, G. C.; PAZ, C. C. P.; BEZERRA, L. A. F.; LOBO, R. B.; OLIVEIRA, J. A.; MUNARI, D. P. Genetic associations between age at first calving and heifer body weight and scrotal circumference in Nelore cattle. Journal Animal Breeding Genetics, v. 126, p. 387-393, 2009.

MAGNABOSCO, C. U.; BARBOSA, V.; FARIA, C. U.; LOPES, D. T.; VIU, M. A. O.; MAMEDE, M. M. S.; LÔBO, R. B. Estudo genético quantitativo de características de carcaça medidas por ultrassom e perímetro escrotal utilizando inferência bayesiana em novilhos Nelore. Planaltina: EMBRAPA Cerrados, 2009. (Boletim de Pesquisa e Desenvolvimento, 247).

MAGNABOSCO, C. U.; SAINZ, R. D.; FARIA, C. U.; YOKOO, M. J.; MANICARDI, F.; BARBOSA, V.; GUEDES, C.; LEME, P. R.; PEREIRA, A.; ARAUJO, F. R. C.; SANCHES, A. C.; LOBO, R. B. Avaliação genética e critérios de seleção para características de carcaça em zebuínos: relevância econômica para mercados globalizados. In: SIMPÓSIO INTERNACIONAL DE PRODUÇÃO DE GADO DE CORTE, 1., 2006, Viçosa, MG. Anais... Viçosa, MG, UFV, 2006. p. 239-271.

MERCADANTE, M. E. Z.; LÔBO, R. B.; OLIVEIRA, H. R. Estimativas de (co)variâncias entre características de reprodução e de crescimento em fêmeas de um rebanho Nelore. Revista Brasileira de Zootecnia, Viçosa, MG, v. 29, n. 4, p. 997-1004, 2000.

OWENS, F. N., DUBESKI, P., HANSON, C. F. Factors that alter the growth and development of ruminants. Journal of Animal Science, Champaign, v. 71, n. 11, p. 3138-3150, 1993.

PEREIRA, E.; ELER, J. P.; COSTA, F. A. A.; FERRAZ, J. B. S. Análise genética da idade ao primeiro parto e do perímetro escrotal em bovinos da raça Nelore. Arquivo Brasileiro de Medicina Veterinária e Zootecnia, Belo Horizonte, v. 53, n. 1, p. 116-121, 2001. 
PEREIRA, E.; ELER, J. P.; FERRAZ, J. B. S. Análise genética de características reprodutivas na raça Nelore. Pesquisa Agropecuária Brasileira, Brasília, v. 37, n. 5, p. 703-708, 2002.

Correlação genética entre perímetro escrotal e algumas características reprodutivas na raça Nelore. Revista Brasileira de Zootecnia, Viçosa, MG, v. 29, n. 6, p. 1676-1683, 2000.

PEREIRA, M. C.; YOKOO, M. J.; GIGNARDI, A. B.; SEZANA, J. C.; ALBUQUERQUE, L. G. Altura da garupa e sua associação com características reprodutivas e de crescimento na raça Nelore. Pesquisa Agropecuária Brasileira, Brasília, v. 45, n. 6, p. 613-620, 2010.

R DEVELOPMENT CORE TEAM - R. A language and environment for statistical computing. Vienna: R Foundation for Statistical Computing, 2012. Available at: $\quad<$ http://www..R-project..org $>$. Accessed at: 10 ago. 2013.

ROBERTSON, A. The sampling variance of the genetic correlation coefficient. Biometrics, Arlington, v. 15, n. 3, p. 469-485, 1959.

SILVEIRA, J. C.; McMANUS, C.; MASCIOLI, A. S.; SILVA, L. O. C.; SILVEIRA, A. C.; GARCIA, J. A. S.; LOUVANDINI, H. Fatores ambientais e parâmetros genéticos para características produtivas e reprodutivas em um rebanho no estado do Mato Grosso do Sul. Revista Brasileira de Zootecnia, Viçosa, MG, v. 33, n. 6, p. 1432-1444, 2004.

TALHARI, F. M.; ALENCAR, M. M.; MASCIOLI, A. S. Correlações genéticas entre características produtivas de fêmeas em um rebanho da raça Canchim. Revista Brasileira de Zootecnia, Viçosa, MG, v. 32, n. 4, p. 880-886, 2003.
VAN TASSEL, C. P.; VAN VLECK, L. D. Multipletrait Gibbs sampler for animal models: flexible programs for Bayesian an likelihood-based (co) variance components inference. Journal of Animal Science, Champaign, v. 74, n. 11, p. 2586-2597, 1996.

YOKOO, M. J. Análise Bayesiana da área de olho do lombo e da espessura de gordura obtidas por ultrassom e suas associações com outras características de importância econômica na raça Nelore. 2009. Tese (Doutorado em Genética e Melhoramento Animal) - Universidade Estadual Paulista. Faculdade de Ciências Agrárias e Veterinárias, Jaboticabal.

YOKOO, M. J.; ALBUQUERQUE, L. G.; LOBO, R. B.; BEZERRA, L. A. F.; ARAUJO, F. R. C.; SILVA J. A. V.; SAINZ, R. D. Genetic and environmental factors affecting ultrasound measures of longissimus muscle area and backfat thickness in Nelore cattle. Livestock Science, v. 117, n. 2-3, p. 147-154, 2008.

YOKOO, M. J.; MAGNABOSCO, C. U.; ROSA, G. J. M.; LOBO, R. B.; ALBUQUERQUE, L. G. Características reprodutivas e suas associações com outras características de importância econômica na raça Nelore. Arquivo Brasileiro de Medicina Veterinária e Zootecnia, Belo Horizonte, v. 64, n. 1, p. 91-100, 2012.

YOKOO, M. J.; WERNECK, J. N.; PEREIRA, M. C.; ALBUQUERQUE, L. G.; KOURY FILHO, W.; SAINZ, R. D.; LOBO, R. B.; ARAUJO, F. R. C. Correlações genéticas entre escores visuais e características de carcaça medidas por ultrassom em bovinos de corte. Pesquisa Agropecuária Brasileira, Brasília, v. 44, n. 2, p. 197-202, 2009. 